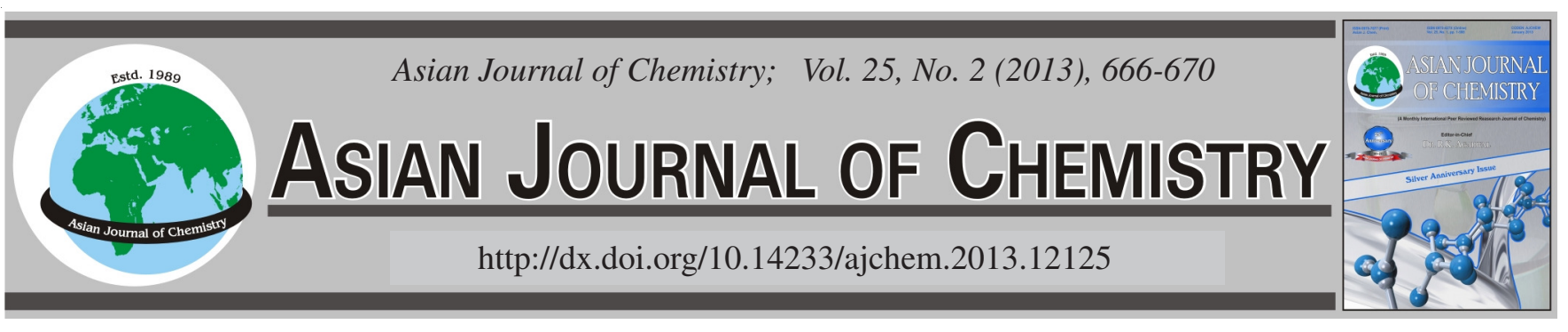

\title{
Antimicrobial and Antioxidant Activities of Some Species of Centaurea Collected from Turkey
}

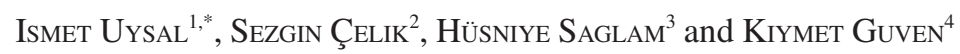

\begin{abstract}
${ }^{1}$ Department of Biology, Faculty of Science and Arts, Canakkale Onsekiz Mart University, TR-17020 Canakkale, Turkey ${ }^{2}$ Department of Elemantary Education, Faculty of Education, Kirikkale University, TR-71451 Kirikkale, Turkey

${ }^{3}$ Department of Pharmacognosy, Faculty of Pharmacy, Ege University, TR-35100 Izmir, Turkey

${ }^{4}$ Department of Biology, Faculty of Science, Anadolu University, TR-26470 Eskisehir, Turkey
\end{abstract}

*Corresponding author: Fax: +90 286218 0533; Tel: +90286 2180018/1868; E-mail: ismetuysal@ gmail.com

\begin{abstract}
The antimicrobial activity of the ethanol, acetone, ethyl acetate and chloroform extracts from Centaurea persica Boiss., C. polyclada DC. and $C$. consanguinea DC. (Asteraceae) were investigated by agar-well diffusion assay. All of the extracts exhibited an antimicrobial effect against most of the bacteria and all of the yeasts tested. The plant extracts were also screened for radical scavenging potential using a 1,1diphenyl-2-picryl-hydrazyl (DPPH) in vitro model system for antioxidant activity. Ethyl acetate extracts showed the most significant inhibitory activity. Therefore, the minimal inhibitory concentration (MIC) of only ethyl acetate extracts of the samples was determined and $C$. consanguinea showed the highest antimicrobial effect. However, the ethanol extract of $C$. polyclada at $0.5 \mathrm{mg} / \mathrm{mL}$ concentration displayed the highest antioxidant activity. This activity was followed by ethanol extracts of. $C$. persica, ethyl acetate extracts of $C$. polclada, C. persica and C. consanguinea respectively.
\end{abstract}

Key Words: Antimicrobial and antioxidant activity, Centaurea persica, C. polyclada and C. Consanguinea.

\section{INTRODUCTION}

Medicinal components from plants play an important role in conventional medicine. People on all continents have long applied poultices and imbibed infusions of thousands of plants, dating back to prehistory ${ }^{1}$. Since their discovery, antimicrobial drugs have remarkably proved to be effective for the control of bacterial infections. The indiscriminative use of antibiotics resulted in the emergence of a number of resistant bacterial strains and the antimicrobial compounds from plants may inhibit bacteria by a different mechanism than the antibiotics presently used and may have clinical value in the treatment of resistant microbial strains ${ }^{2}$.

On the other hand, research in herbal medicine has increased in developing countries as a way to rescue ancient traditions as well as an alternative solution to health problem in cities. Therefore, with the increasing acceptance of traditional medicine as an alternative way of health care, the screening of plants for active compounds has become very important. Many species of genus Centaurea L. (Asteraceae) have traditionally been used for the treatment of various ailments ${ }^{3,4}$. The genus Centaurea has been the subject of many antimicrobial and antioxidant activity properties ${ }^{5-17}$.

The plants possess potent bioactive compounds capable of preventing and treating most oxidative related diseases.
Natural antioxidants are known to exhibit a wide range of biological effects, including antiviral, antibacterial, antiinflammatory, antiallergic and antitrombotic activity. Therefore natural antioxidants have become a major area of scientific searches. The importance of searching for and exploiting natural antioxidants especially those of plant origin has increased remarkably in recent years ${ }^{18,19}$.

In this study, antimicrobial properties of ethanol, acetone, ethyl acetate and chloroform extracts of 3 types Centaurea taxa namely, Centaurea persica Boiss., C. polyclada DC. and C. consanguinea DC., which were collected from Turkey were investigated against both clinical and food borne microorganisms (bacteria and yeasts) by using agar-well diffusion assay. Another objective of the present study was to assess the antioxidant potential of endemic Centaurea species as a source of antioxidants for nutritional and therapeutic purposes. In vitro antioxidant assay (DPPH scavenging activity) was performed for $C$. consanguinea, $C$. polyclada and $C$. persica extracts prepared with solvents having different polarities.

\section{EXPERIMENTAL}

Plant materials and extraction procedure: Three endemic Centaurea taxa of Turkish samples ${ }^{20,21}$ were collected from original (typical) localities in Turkey by Celik and Uysal. 
C. persica Boiss. was collected in the region stretching from Sirnak to Yüksekova (July 2009, $1950 \mathrm{~m})$, C. polyclada DC. was collected from Çanakkale Intepe (June 2009, $50 \mathrm{~m}$ ) and C. consanguinea DC. was collected in the region extending from Mus to Bingöl (June 2009, 1100 m). The specimens collected were identified with the help of Flora of Turkey and the East Aegean Islands ${ }^{20}$. Voucher specimens were deposited in the Herbarium of Faculty of Science and Arts, Canakkale Onsekiz Mart University (COMU). Collector numbers were the same numbers as the numbers given by Celik and Uysal. The plants previously were air-dried and then aerial parts (stem, leaf, flower and fruit) were ground with the help of a Waring blender. Ground samples $(20 \mathrm{~g})$ were extracted with $150 \mathrm{~mL}$ of ethanol, acetone, ethyl acetate and chloroform solvent (Merck, Darmstadt, Germany) for $24 \mathrm{~h}$ by using Soxhlet equipment. The extracts were filtered by using Whatman filter paper (No. 1) and then were concentrated in vacuo at $70{ }^{\circ} \mathrm{C}$. The residues were stored in a refrigerator until subsequent use. For the bioassay the extracts were suspended in the same solvents (ethanol, acetone, ethyl acetate and chloroform) at a concentration of $10 \mathrm{mg} / \mathrm{mL}$ for the bioassay.

Microorganism: A total of 29 microbial genera including 26 bacteria and 3 yeast species were used in this study. Table- 1 shows the isolates and their source of origin used in the study.

Antimicrobial activity: The antimicrobial activities of the ethanol, acetone, ethyl acetate and chloroform extracts were evaluated by means of the agar-well diffusion assay ${ }^{22,23}$ with some modifications. Twenty milliliters of the specified molten agar $\left(45^{\circ} \mathrm{C}\right)$ was poured into $9 \mathrm{~cm}$ sterile Petri dishes. A suspension $(100 \mu \mathrm{L})$ containing $10^{8} \mathrm{cfu} / \mathrm{mL}$ bacteria and $10^{6} \mathrm{cfu} / \mathrm{mL}$ yeasts was spread on the plates of nutrient agar (Merck) and Mueller-Hinton agar (Oxoid, Hampshire, UK) medium, respectively. Once the plates were dried aseptically, $6 \mathrm{~mm}$ wells were bored using a sterile cork borer. Extracts $(50 \mu \mathrm{L})$ were placed into the wells and the plates were incubated for $37^{\circ} \mathrm{C}$ for $24 \mathrm{~h}$ for bacterial strains and $48 \mathrm{~h}$ for yeast. Chloramphenicol $(10 \mathrm{mg} / \mathrm{mL})$ for bacteria and ketakonozol $(10 \mathrm{mg} / \mathrm{mL})$ for yeast were used as standard antibiotics. The tests were carried out in triplicate. Antimicrobial activity was evaluated by measuring zone of inhibition against the test organism.

Microdilution assay: The minimal inhibition concentration (MIC) values were also studied for the microorganisms which were determined as sensitive to the extracts in agarwell diffusion assay ${ }^{11,24,25}$. Stock solution of the ethyl acetate extract which gave the best inhibition in the agar-well diffusion test was prepared in dimethyl sulfoxide (DMSO, Carlo-Erba, France). Dilution series using sterile distilled water were prepared from $2000-3.9 \mu \mathrm{g} / \mathrm{mL}$ in test tubes which were transferred to 96 well microtiter plates. Overnight grown bacterial and yeast suspensions in double strength Mueller Hinton Broth were standardized to $10^{8} \mathrm{cfu} / \mathrm{mL}$ using McFarland No: 0.5 standart solution. Microorganism suspension $(100 \mu \mathrm{L})$ was then added into the wells. The last-well chain without microorganism was used as a negative control. Sterile distilled water and the medium served as a positive growth control. After incubation at $37^{\circ} \mathrm{C}$ for $18 \mathrm{~h}$ the first well without turbidity was determined as the minimal inhibitory concentration (MIC). Chloramphenicol was used as standard antibacterial agent.

\section{TABLE-1}

STRAINS USED IN THE STUDY AND THEIR SOURCE

\begin{tabular}{|c|c|}
\hline Strain & Source \\
\hline \multicolumn{2}{|l|}{ Bacillus cereus NRRL B-3711 } \\
\hline \multicolumn{2}{|l|}{ Bacillus subtilis NRRL 744} \\
\hline \multicolumn{2}{|l|}{$\begin{array}{l}\text { Salmonella typhimurium NRRL B- } \\
4420\end{array}$} \\
\hline \multicolumn{2}{|l|}{ Microccoccus luteus NRRL B-4375 } \\
\hline \multicolumn{2}{|l|}{ Proteus vulgaris NRRL B-123 } \\
\hline $\begin{array}{l}\text { Xanthomonas campestris pv. } \\
\text { campestris }\end{array}$ & $\begin{array}{l}\text { USDA, Agricultural Research } \\
\text { Service, Peoria, IL.US }\end{array}$ \\
\hline \multicolumn{2}{|l|}{ NRRL-B1459 } \\
\hline \multicolumn{2}{|l|}{$\begin{array}{l}\text { Enterobacter aerogenes NRRL B- } \\
3567\end{array}$} \\
\hline \multicolumn{2}{|l|}{$\begin{array}{l}\text { Streptococcocus feacalis NRRL B- } \\
14617\end{array}$} \\
\hline \multicolumn{2}{|l|}{ Rhodotorula rubra NRRL Y-2505 } \\
\hline Escherichia coli ATCC 25922 & Ege University, Faculty of \\
\hline $\begin{array}{l}\text { Staphylococcus aureus ATTC } 6538 \\
\text { T }\end{array}$ & $\begin{array}{l}\text { Science, Dept. of Biology, } \\
\text { Izmir, Turkey }\end{array}$ \\
\hline \multicolumn{2}{|l|}{ Aeromonas hydrophila } \\
\hline Listeria monocytogenes & Ankara University, Faculty of \\
\hline Klebsiella pпеитопiae & Veterinary, Ankara, Turkey \\
\hline Yersinia enterocolitica & \\
\hline \multicolumn{2}{|l|}{ Pseudomonas fluorescens B 130} \\
\hline \multicolumn{2}{|l|}{ Bacillus pumilus $\mathrm{B} 122$} \\
\hline $\begin{array}{l}\text { Pseudomonas syringae pv. tomato } \\
32\end{array}$ & $\begin{array}{c}\text { J. B. Jones, University of } \\
\text { Florida, IFAS, Plant Pathology }\end{array}$ \\
\hline \multirow{2}{*}{\multicolumn{2}{|c|}{ Pseudomonas tobacco 8}} \\
\hline & \\
\hline Pseudomonas syringae-1 & \\
\hline $\begin{array}{l}\text { Pseudomonas syringae pv. glycine } \\
\text { PG1-T }\end{array}$ & $\begin{array}{c}\text { Vidaver, A. K. University of } \\
\text { Nebraska Lincoln, Institute of } \\
\text { Agricultural and Natural } \\
\text { Resources }\end{array}$ \\
\hline \multicolumn{2}{|l|}{$\begin{array}{l}\text { Pseudomonas syringae } \mathrm{pv} . \\
\text { phaseolicola }\end{array}$} \\
\hline NCPPB 52 & J. G: Turner, Univ. of East \\
\hline Pseudomonas gingeri 3146 & Anglia, UK \\
\hline \multicolumn{2}{|l|}{$\begin{array}{l}\text { Pseudomonas gladioli pv. agricola } \\
\text { RR3 }\end{array}$} \\
\hline \multicolumn{2}{|l|}{ Brucella spp. } \\
\hline Pseudomonas maltophila & Osmangazi University Medical \\
\hline Candida albicans & Faculty \\
\hline Candida globrata & \\
\hline
\end{tabular}

Antioxidant activity (DPPH radical scavenging activity): The plant extracts were screened for radical scavenging potential using a 1,1-diphenyl-2-picryl-hydrazyl (DPPH) in vitro model system. The chloroform, acetone, ethyl acetate and ethanol extracts of Centaurea consanguinea, $C$. polyclada and $C$. persica was prepared at a concentration of $0.5 \mathrm{mg} / \mathrm{mL}$. $1000 \mu \mathrm{L}$ of each sample was added to $4 \mathrm{~mL}$ of $0.004 \%$ methanol solution of DPPH. After a $0.5 \mathrm{~h}$ incubation period at room temperature in darkness, the absorbance of mixture was measured at $517 \mathrm{~nm}$ against methanol as blank using a UNICAM 8625 UV/VIS spectrophotometer. Free radical scavenging activity of $\alpha$-tocopherol as reference compound was also determined. The inhibition percentage of the tested samples were evaluated by comparison with a control. Each sample was measured in triplicate and averaged.

The inhibition of free radical by DPPH in percent (I \%) was calculated using the formula:

$$
I(\%)=\left(\frac{A_{c}-A_{s}}{A_{c}}\right) \times 100
$$


where $A_{c}$ is the absorbance of the control and $A_{s}$ is the absorbance of the tested sample after $0.5 \mathrm{~h}$.

The calibration curve with $\alpha$-tocopherol had a concentration ranging between $2.0-3.6 \mathrm{mg} / \mathrm{mL}$ and $\alpha$-tocopherol equivalent antioxidant activities of samples were calculated from the following calibration curve:

$$
\mathrm{y}=12.88 \mathrm{x}-24.451\left(\mathrm{r}^{2}=0.9985\right)
$$

The present study followed principles as described in the Declaration of Helsinki and all requirements was carried out and approved by the University Research Institution.

\section{RESULTS AND DISCUSSION}

The antimicrobial activities of ethanol, acetone, ethyl acetate and chloroform extracts of Centaurea persica; $C$. polyclada and $C$. consanguinea against microorganisms examined in the present study and their potency were qualitatively assessed by the presence or absence of inhibition zones and zone diameter (Table-2).

The microorganisms tested included clinical and foodborne pathogens and plant pathogens. The results showed that the ethyl acetate, acetone, chloroform and ethanol extracts of C. persica, C. polyclada and C. consanguinea had significant antimicrobial activities against many microorganisms tested. All of the isolates tested were susceptible to the ethyl acetate, acetone and ethanol extracts. Only the chloroform extracts out of the the three Centaurea spp. tested did not inhibit the growth of some bacteria and the yeast $R$. rubra (Table-2).

Although the ethyl acetate extract of $C$. consanguinea had greater antimicrobial activity than the other extracts of the plants, the antimicrobial activity of the plant extracts was not higher than the standard antibiotics of chloramphenicol and ketakonozol. Plant pathogenic Pseudomonas syringae pv. phaseolicola, Pseudomonas syringae, Xanthomonas campestris pv. campestris and Pseudomonas gladioli pv. agricola and human pathogenic Yersinia enterocolitica were the most susceptible to the ethyl acetate extract of $C$. consanguinea (Table-2).

Ethyl acetate extracts of the samples exhibited stronger and broader spectrum of antimicrobial activity as compared to ethanol, acetone and chloroform extracts. Therefore in the determination of minimal inhibitory concentration (MIC) only the ethyl acetate extracts of the three Centaurea sp. were used against some bacteria chosen from agar-well diffusion assay. MIC values of the extracts were observed between 250-125 $\mu \mathrm{g} / \mathrm{mL}$ (Table-3).

Kumarasamy et al. ${ }^{9}$ tested Centaurea scabiosa seeds for antimicrobial activity and found that the extracts were effective only to Proteus mirabilis bacterium. Kumarasamy et al. ${ }^{3}$ found significant antimicrobial activity of serotonin conjugates from C. nigra against penicillin-resistant E. coli. However, little antimicrobial activity was observed against this bacterium in this study.

\begin{tabular}{|c|c|c|c|c|c|c|c|c|c|c|c|c|c|}
\hline \multicolumn{14}{|c|}{$\begin{array}{l}\text { TABLE-2 } \\
\text { ANTIMICROBIAL ACTIVITY OF } C \text {. persica, } C \text {. polyclada AND C. consanguinea EXTRACTS AGAINST THE BACTERIAL, } \\
\text { YEAST AND FUNGAL STRAINS TESTED BASED ON AGAR WELL DIFFUSION METHOD }\end{array}$} \\
\hline \multirow{3}{*}{ Microorganisms } & \multicolumn{13}{|c|}{ Inhibiton zone in diameter (mm/sensitive strains) } \\
\hline & \multicolumn{4}{|c|}{ C. persica } & \multicolumn{4}{|c|}{ C. polyclada } & \multicolumn{4}{|c|}{ C.consanguinea } & \multirow{2}{*}{$\begin{array}{l}\text { Standard } \\
\text { antibiotic }\end{array}$} \\
\hline & A & $\mathrm{B}$ & $\mathrm{C}$ & $\mathrm{D}$ & A & $\mathrm{B}$ & $\mathrm{C}$ & $\mathrm{D}$ & A & $\mathrm{B}$ & $\mathrm{C}$ & $\mathrm{D}$ & \\
\hline Klebsiella pneumoniae & 15 & 19 & 8 & 12 & 8 & 8 & 8 & 12 & 17 & 16 & 8 & 9.5 & 29 \\
\hline Staphylococcus aureus & 14 & 13 & 9 & 14 & 13 & 10 & 8 & 12 & 18 & 12 & 8 & 16 & 35 \\
\hline Bacillus pumilus & 15 & 14 & 8 & 13 & 13 & 10 & 8 & 12 & 18 & 9 & 8 & 8 & 28 \\
\hline Aeromonas hydrophila & 17 & 13 & - & 20 & 16 & 13 & - & 18 & 22 & 11 & - & 14 & 31 \\
\hline Bacillus cereus & 17 & 14 & 13 & 17 & 20 & 10 & 9 & 17 & 21 & 22 & - & 16 & 33 \\
\hline Yersinia enterocolitica & 13 & 17 & 10 & 22 & 16 & 15 & - & 12 & 26 & 15 & - & 24 & 29 \\
\hline Salmonella typhimurium & 11 & 19 & 13 & 22 & 24 & 14 & 8 & 15 & 22 & 14 & 9 & 18 & 35 \\
\hline Listeria monocytogenes & 13 & 18 & - & 12 & 10 & 9 & 8 & 10 & 12 & 12 & - & 9 & 32 \\
\hline Brucella spp. & 15 & 8 & 7 & 8 & 14 & 12 & 7 & 8 & 19 & 16 & 8 & 13 & 30 \\
\hline Bacillus subtilis & 14 & 12 & 7 & 9 & 16 & 11 & 9 & 12 & 20 & 12 & 9 & 15 & 39 \\
\hline Enterobacter aerogenes & 17 & 11 & - & 8 & 14 & 14 & 9 & 14 & 18 & 15 & 8 & 10 & 34 \\
\hline Proteus vulgaris & 12 & 16 & 7 & 12 & 8 & 13 & 8 & 12 & 18 & 10 & - & 11 & 25 \\
\hline Pseudomonas maltophila & 15 & 9 & 7 & 10 & 13 & 10 & 10 & 10 & 20 & 15 & 8 & 9 & 37 \\
\hline Escherichia coli & 15 & 8 & 8 & 9 & 12 & 11 & 8 & 9 & 17 & 14 & 11 & 10 & 39 \\
\hline Microccoccus luteus & 16 & 12 & 8 & 12 & 17 & 10 & - & 9 & 22 & 18 & 10 & 12 & 44 \\
\hline Streptococcocus feacalis & 8 & 10 & 7 & 8 & 8 & 9 & - & 9 & 20 & 14 & 8 & 8 & 29 \\
\hline Candida albicans & 13 & 11 & 8 & 9 & 13 & 12 & 9 & 9 & 16 & 13 & 12 & 10 & 29 \\
\hline Candida globrata & 11 & 8 & 8 & 9 & 16 & 10 & 8 & 8 & 18 & 11 & 9 & 11 & 29 \\
\hline Pseudomonas gladioli pv. agricola & 11 & 14 & 8 & 11 & 13 & 12 & 9 & 14 & 22 & 14 & 8 & 11 & 28 \\
\hline Pseudomonas lachrymans & 17 & 20 & 8 & 15 & 14 & 12 & - & 14 & 19 & 17 & 8 & 15 & 23 \\
\hline Xanthomonas campestris pv. campestris & 17 & 14 & 8 & 15 & 20 & 13 & - & 15 & 23 & 19 & 11 & 13 & 38 \\
\hline Pseudomonas syringae & 20 & 18 & - & 18 & 18 & 14 & - & 15 & 25 & 14 & 8 & 14 & 36 \\
\hline Pseudomonas gingeri & 15 & 13 & 10 & 10 & 16 & 11 & - & 12 & 19 & 12 & 10 & 8 & 42 \\
\hline Pseudomonas syringae pv. glycine & 19 & 18 & - & 19 & 8 & 14 & - & 22 & 19 & 15 & - & 12 & 39 \\
\hline Pseudomonas syringae pv. tomato & 22 & 16 & - & 12 & 10 & 10 & - & 12 & 22 & 16 & - & 17 & 41 \\
\hline Pseudomonas tobacco & 15 & 12 & 7 & 9 & 12 & 11 & - & 12 & 17 & 11 & 13 & 10 & 39 \\
\hline Pseudomonas syringae pv. phaseolicola & 15 & 12 & 8 & 8 & NT & NT & NT & NT & 30 & 18 & 9 & 9 & 42 \\
\hline Pseudomonas fluorescens & 10 & 18 & 7 & 9 & 13 & 11 & - & 9 & 17 & 11 & 18 & 11 & 26 \\
\hline Rhodotorula rubra & 16 & 10 & - & 12 & 10 & 11 & 9 & 14 & 17 & 12 & 8 & 12 & 37 \\
\hline
\end{tabular}

A: Ethyl acetate extract; B: Acetone extract; C: Chloroform extract and D: Ethanol extract. NT: Not tested. 


\begin{tabular}{lcccc}
\hline \multicolumn{5}{c}{$\begin{array}{c}\text { TABLE-3 } \\
\text { MIC VALUES OF Centaurea persica; C. polyclada AND C. consanguinea EXTRACTS AGAINST } \\
\text { THE MICROORGANISMS TESTED IN MICRODILUTION ASSAY (MIC in } \mu \mathrm{g} / \mathrm{mL} \text { ) }\end{array}$} \\
\cline { 2 - 5 } \multicolumn{1}{c}{ Microorganisms } & \multicolumn{4}{c}{ Ethyl acetate_extracts } \\
\hline \multicolumn{2}{c}{ C. persica } & C. polyclada & C. consanguinea & Standard antibiotic \\
\hline Pseudomonas lachrymans & 250 & 250 & 250 & 250 \\
Pseudomonas syringae & 125 & 125 & 125 & 15.62 \\
Bacillus cereus & 250 & 250 & 250 & 125 \\
Pseudomonas syringae pv. tomato & 250 & 250 & 250 & 250 \\
Pseudomonas syringae pv. glycine & 125 & 125 & 125 & 15.62 \\
Xanthomonas campestris pv. campestris & 250 & 125 & 125 & 7.81 \\
Pseudomonas syringae pv. phaseolicola & 250 & 250 & 250 & 15.62 \\
\hline
\end{tabular}

The essential oils of air-dried Centaurea sessilis and Centaurea armena were analyzed for antimicrobial activity and, moderate activity was obtained ${ }^{12}$. The extracts showed better antimicrobial activity against $\mathrm{Gr}(+)$ bacteria when compared to $\mathrm{Gr}(-)$ bacteria.

In the previous study ${ }^{11}$ of antimicrobial activity of other Centaurea species namely, C. ptosomipapapoides, C. odyssei, C. ptosomipappa and $C$. kurdica, it was found that the extracts exhibited antibacterial and antiyeast effect and ethyl acetate extracts showed the most significant inhibitory activity. In this study, we obtained similar results with the earlier study ${ }^{11}$ showing that ethyl acetate extracts of the plants were the most active.

This study was the first record of antimicrobial activity of aerial plant extracts of Centaurea persica, C. polyclada and C. consanguinea and a moderate antimicrobial activity was observed against the bacteria and yeasts tested.

The hydrogen atom or electron donation abilities of plant extracts were measured from bleaching of the purple coloured methanol solution of DPPH. The model of scavenging the stable DPPH radical is widely used to evaluate the antioxidant activities. DPPH is a stable free radical with a characteristic absorbtion at $517 \mathrm{~nm}$ and as the antioxidants donate protons to these radicals, the absorbtion decreases. The decrease in absorbtion is taken as a measure of radical scavenging activity.

Table-4 shows the antioxidant effect of solvent extracts of Centaurea species. The antioxidant activity was shown in terms of inhibiton per cent of DPPH and activity equivalent to antioxidant reference compound $\alpha$-tocopherol. Different solvents of varying polarities were used for the extraction of Centaurea species. The results revealed that acetone, ethyl acetate, chloroform and ethanol extracts of Centaurea consanguinea, C. polyclada and C. persica exhibited varying scavenging capacities.

The ethanol extract of C. polyclada at $0.5 \mathrm{mg} / \mathrm{mL}$ concentration displayed the highest antioxidant activity with $43.23 \%$ inhibiton and $5.26 \mathrm{mg} / \mathrm{mL} \alpha$-tocopherol equivalent activity. This activity was followed by ethanol extracts of C. persica $(38.22 \%)$, ethylacetate extracts of $C$. polclada (28.21\%), C. persica (28.21\%) and C. consanguinea (25.14 $\%$ ), respectively. The lowest scavenging activity was exhibited by the chloroform extract of $C$. polyclada with $1.93 \%$ free radical inhibiton and $\alpha$-tocopherol equivalent activity as 2.04 $\mathrm{mg} / \mathrm{mL}$. In comparison with the other solvents, except for $C$. consanguinea, all the chloroform extracts of plant materials were found to have lowest antioxidant activity.

Numerous substances have beeen suggested to appear as antioxidants. The detailed investigations were so far concerned with reactions involving phenolic compounds ranging from polymer chemistry to biochemistry and food chemistry. It has been revealed that various phenolic antioxidants such as flavonoids, tannins, coumarins, procyanidins scavenge radicals dose-dependently. On the basis of the results of this study, the extraction of antioxidant compounds depends largely on type of solvent. To the best of our knowledge, this is the first report of the antioxidant activity of Centaurea persica, C. polyclada and $C$. consanguinea. The ethanol and ethyl acetate extraction could be recommended for being most suitable method for the isolation of compounds responsible for the antioxidant activity.

\section{ACKNOWLEDGEMENTS}

The authors are grateful to Ms. Ferda Cetintas for her technical assistance.

\begin{tabular}{clcc}
\hline & \multicolumn{3}{c}{ FREE RADICAL SCAVENGING ACTIVITY OF THE Centaureae EXTRACTS } \\
\hline \multirow{3}{*}{ Solvent } & \multicolumn{1}{c}{ Plant extract $(0.5 \mathrm{mg} / \mathrm{mL})$} & DPPH $\%$ inhibition & $\alpha$-Tocopherol equivalent antioxidant activity $(\mu \mathrm{gg} / \mathrm{mL})$ \\
\hline \multirow{3}{*}{ Ethyl acetate } & Centaurea persica & 28.21 & 4.09 \\
& Centaurea polyclada & 28.21 & 4.09 \\
& Centaurea consanguinea & 25.14 & 3.85 \\
\hline \multirow{3}{*}{ Acetone } & Centaurea persica & 7.96 & 2.52 \\
& Centaurea polyclada & 13.08 & 2.91 \\
& Centaurea consanguinea & 4.09 & 2.21 \\
\hline \multirow{3}{*}{ Chloroform } & Centaurea persica & 2.51 & 2.09 \\
& Centaurea polyclada & 1.93 & 2.04 \\
& Centaurea consanguinea & 16.84 & 3.21 \\
\hline \multirow{3}{*}{ Ethanol } & Centaurea persica & 38.22 & 4.87 \\
& Centaurea polyclada & 43.23 & 5.26 \\
& Centaurea consanguinea & 24.46 & 3.79 \\
\hline
\end{tabular}




\section{REFERENCES}

1. M.M. Cowan, Clin. Microbiol. Rev., 12, 546 (1999).

2. J.N. Elof, J. Ethnopharmacol., 160, 1 (1998).

3. Y. Kumarasamy, M. Middleton, R.G. Reid, L. Nahar and S.D. Sarker, Fitoterapia, 74, 609 (2003).

4. I. Uysal, S. Celik and M. Oldacay, Pak. J. Biol. Sci., 8, 1812 (2005).

5. V. Vaajs, N. Todorovic, M. Ristic, V. Tesevic, B. Todorovic, P. Janackovic, P. Marin and S. Milosavlievic, Phytochemistry, 52, 383 (1999).

6. E. Yesilada, I. Gurbuz and H. Shibata, J. Ethnopharmacol., 66, 289 (1999).

7. H. Skaltsa, D. Lazari, C. Panagouleas, E. Georgiadou, B. Garcia and M. Sokovic, Phytochemistry, 52, 383 (2000).

8. A. Karioti, H. Skaltsa, D. Lazari, M. Sokovic and C.G. Harvala, Z. Naturforsch, 57c, 75 (2002).

9. Y. Kumarasamy, P.J. Cox, M. Jaspars, L. Nahar and S.D. Sarker, J. Ethnopharmacol., 83, 73 (2002).

10. E. K. Barbour, M.A. Sharif, V.K. Sagherian, A.N. Habre, R.S. Talhouk and S.N. Talhouk, J. Ethnopharmacol., 93, 1 (2004).

11. K. Guven, S. Celik and I. Uysal, Pharm. Biol., 43, 67 (2005).

12. N. Yayli, A. Yasar, C. Gulec, A. Usta, S. Kolayli, K. Coskuncelebi and S. Karaoglu, Phytochemistry, 66, 1741 (2005).

13. M.I. Skliar, M.S. Toribio and D.S. Oriani, Fitoterapia, 76, 737 (2005).

14. R. Arif, E. Kupeli and F. Ergun, J. Sci. Gazi Univ., 17, 149 (2004).
15. Y. Tekeli and M. Sezgin, Süleyman Demirel Univ. J. Faculty Sci. Art, 2, 204 (2007).

16. Y. Tekeli, M. Sezgin and M.A. Sanda, Süleyman Demirel Univ. J. Faculty Sci. Art, 3, 35 (2008)

17. Y. Tekeli, M. Sezgin and A. Aktümsek, Asian J. Chem., 20, 4831 (2008).

18. S.A. Dahanuka, R.A. Kulkarni and N.N. Rege, Indian J. Pharmacol., 32, 81 (2000).

19. C.M. Liyana-Pathirana and F. Shahidi, J. Sci. Food. Agric., 86, 477 (2006).

20. G. Wagenitz, In ed.: P.H. Davis, Centaurea L. Flora of Turkey and the East Aegean Islands, Edinburg University Press, Edinburgh, pp. 490556 (1975).

21. T. Ekim, M. Koyuncu, M. Vural, H. Duman, Z. Aytaç and N. Adigüzel, Red Data Book of Turkish Plants, Turkish Association for the Conservation of Nature and Van Centennial University Publishing (2000).

22. R. Rojas, B. Bustamante, J. Bauer, I. Fernandez, J. Alban and O. Lock, J. Ethnopharmacol., 88, 199 (2003).

23. F. Sahin, I. Karaman, M. Gulluce, H. Ögütçü, M. Sengül, A. Adigüzel and R. Kotan, J. Ethnopharmacol., 87, 61 (2003).

24. E.W. Koneman, S.D. Allen, W.M. Janda, P.C. Schreckenberger and W.C. Winn, Color Atlas and Textbook of Diagnostic Microbiology, Lippincott-Raven Publ, Philadelphia (1997).

25. J.R. Zgoda and J.R. Porter, Pharm. Biol., 39, 221 (2001). 